\title{
CHARACTERISTICS OF LAMINATED WOOD OF LOGGING WASTE OF THREE NATURAL FOREST WOOD SPECIES
}

\author{
Jamaludin Malik, Adi Santoso and Han Roliadi ${ }^{1}$
}

\begin{abstract}
This research is aimed to assess the characteristics of 3-ply laminated wood assembly incorporating wood waste belonged to three species i.e. bengkal (Nauclea sp.), pisang-pisang (Alponsea teysmanii Boerl), and jambu-jambu (Eugenia spp.). The waste was procured from logged natural forests. The used adhesive was tannin-resorcinol formaldehyde. The lamination experiment was replicated three times. The assessed characteristics were moisture content, density, formaldehyde emission, bonding strength, wood defect, and static bending strength.

The resulting 3-ply laminated wood assembly (beam) has a moisture content at $4.00-13.90 \%$, density $0.30-0.68$ gram per $\mathrm{cm}^{3}$, and formaldehyde emission $0.323-3.199 \mathrm{mg}$ per liter that tended to increase with the decrease in density of the laminated wood. The bonding strength of the laminated wood ranges varied from 47.14 to $107.52 \mathrm{~kg}$ per $\mathrm{cm}^{2}$ (dry testing) and $40.76-79.57 \mathrm{~kg}$ per $\mathrm{cm}^{2}$ (wet testing). Likewise, wood defect was about $80-100 \%$ (dry test) and $20-80 \%$ (wet test). Static bending strength varied from 455.62 $843.36 \mathrm{~kg}$ per $\mathrm{cm}^{2}$ (for MOE) and from 35,985.49 to $104,332.63 \mathrm{~kg}$ per $\mathrm{cm}^{2}$ (for MOR). Based on these data, the three wood waste species afforded good bending strength and they were suitable for reconstituting material for exterior-type laminated wood beam.
\end{abstract}

Keywords: laminated beam, laminated wood, characteristics, wood waste, formaldehyde emissions

\section{INTRODUCTION}

Volume of wood waste from forest logging is quite high. Results of an assessment revealed that the waste constitutes 25 - 50\% of the logs removed during logging (Sugiri, 1981; Widarmana, 1984; and Budiaman, 2000). If that percentage is linked to the volume of national log production which currently reaches about 8 million $\mathrm{m}^{3}$ (Anonim, 2003a), then the amount of forest logginggenerated waste is quite substantial.

The utilization of those logging wastes is not yet optimal. When the wood logs are sawn, they produce sawn timber with narrow and short sizes. This situation renders low recovery of sawn timber from the input material (i.e. wood logs), thereby creating also abundant amount of wood residues and hence lowering wood-processing efficiency. Lamination technology can be an effective solution, since it allows to utilize wood pieces up to smaller sizes (e.g. logging wastes and wood-processing residues). Feirer, et al. (1997) in Dansoh, et al. (2004) asserted that conventional solid wood beams with various shapes began to be gradually replaced by laminated wood products. According to Moody, et al. (1999), laminated wood (glue-laminated beam) was first used for auditorium construction in 1893 in Basel (Switzerland), Europe. In the middle of 1930 until 1980, most of the glue-laminated (glulam) products were found their remarkable uses in the United States. During 1990s, export market had been so developed that the glulam products were

${ }^{1}$ Forest Products Technology Research and Development Center, Bogor 
shipped to the Pacific-rim countries, particularly Japan.

Various lamination techniques can be developed either in flatwise, edgewise, or lengthwise directions. Flatwise lamination is intended to produce laminated wood beams used for assembling table mat, wall, or door. Meanwhile, edgewise lamination is to provide beams for components of window or door frames, table legs, lathed products, and handcraft. Finally, lengthwise lamination is to obtain beams with desired length. Commensurate with the more limited solid-wood supply for construction uses, utilization of wood waste through the implementation of lamination technology can be a substituting material. This is because laminated wood can perform as one of the appropriate alternative materials for wood-waste utilization. Sinaga (1989) asserted that there are several advantages of laminated wood, such as: ability to manufacture products with larger, longer, wider, and thicker sizes; and versatility to produce bent or arching laminated assembly with various cross-section area depending on the load centralization, which is difficult to obtain from solid wood.

Laminated wood for exterior uses is usually assembled using humidity-resistant adhesives, such as phenol formaldehyde, resorcinol formaldehyde, or the likes. Those adhesives currently become difficult to obtain, since they are derived from fossil oil. Nowadays, alternative adhesives which are renewable have been popularly developed from tannin-based compounds. Those compounds are extracted from wood bark of Acacia mangium trees. These trees can produce tannin in abundant amount, thereby allowing its utilization as an adhesive (Santoso and Pari, 2001).

This article reports experiment results of laminated wood assembled with three species of wood waste generated from the logging of natural forest, using tannin-based adhesive.

\section{MATERIALS AND METHOD}

\section{A. Materials and Equipment}

The materials were wood logs procured from trunk portions of three small-diameter tree species, i.e. bengkal (Nauclea sp.), pisang-pisang (Alponsea teysmanii Boerl), and jambu-jambu (Eugenia spp.) trees. Those small-diameter trees for the wood logs were wood waste from logging activities of natural forest in Riau (Sumatera). Diameter of the logs were $2050 \mathrm{~cm}$ and the length were up to $150 \mathrm{~cm}$.

The used tannin-based adhesive was a formula containing tannin, resorcinol, and paraformaldehyde hardener (TRF). TRF adhesive was prepared shortly before gluing process in that tannin. The resorcinol was mixed together followed by the addition of paraformaldehyde. Characteristics of the TRF adhesive are presented in Table 1. 
Table 1. Physical and chemical properties of tannin-resorcinol-paraformaldehyde (TRF) adhesive

\begin{tabular}{|l|c|}
\hline \multicolumn{1}{|c|}{ Properties } & Values \\
\hline Visual test & $(+)$ \\
Sticky matter & $(-)$ \\
Gelatinous time (minutes) & 154 \\
Solid content $(\%)$ & 56.01 \\
Viscosity at $25+1^{\circ} \mathrm{C}$ (poise) & 1.85 \\
$\mathrm{pH}$ & 10.5 \\
Free formaldehyde, $\%$ & 0.30 \\
Specific gravity & 1.08 \\
\hline
\end{tabular}

Remarks: $(+)=$ Liquid with brown to black color and phenolic smells; $(-)=($ None $)$

\section{B. Methods}

Each wood $\log$ with particular diameter $(2050 \mathrm{~cm}$ ) and length (up to $150 \mathrm{~cm}$ ) were converted into thin pieces, measuring $2.5 \mathrm{~cm}$ (thickness) by $100 \mathrm{~cm}$ (width) by $50 \mathrm{~cm}$ (length). Those thin wood pieces (wood laminates) should be smooth on their surface, homogenous in their texture and sizes, and free of defects. The wood laminates were then dried until reaching $812 \%$ moisture content.

The surfaces of each dried laminates were spread with TRF adhesive at 170 gram per $\mathrm{m}^{2}$ of surface area, using a brush. As many as three adhesive-spread laminates were used for the assembling of 3-ply laminated wood. The assembling was conducted by piling-up three wood laminates vertically, and it was arranged in flatwise direction (Figure 1). The composition of those three wood laminates in the 3-ply laminated assembly was manipulated in such a way that they could consist of single (one) species or two different species of wood waste origin (i.e. bengkal, pisang-pisang and jambu-jambu). Details of manipulating the composition of wood laminates were described in Table 2.

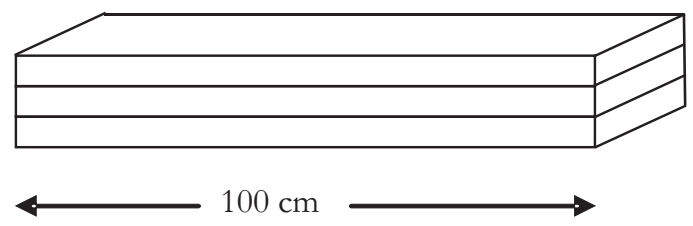

Figure 1. Arrangement of 3-ply laminated wood in flatwise direction 
Table 2. Manipulated composition of wood laminates in flatwise 3-ply laminated wood ${ }^{1)}$

\begin{tabular}{|l|c|}
\hline Manipulated composition $^{2}$ & Codes \\
\hline bengkal-bengkal-bengkal $^{2)}$ & $\mathrm{K}_{1}$ \\
\hline jambu-jambu-jambu $^{2)}$ & $\mathrm{K}_{2}$ \\
\hline pisang-pisang-pisang $^{2)}$ & $\mathrm{K}_{3}$ \\
\hline jambu-bengkal-jambu $^{3)}$ & $\mathrm{K}_{4}$ \\
\hline jambu-pisang-jambu $^{3)}$ & $\mathrm{K}_{5}$ \\
\hline pisang-bengkal-pisang $^{3)}$ & $\mathrm{K}_{6}$ \\
\hline
\end{tabular}

Remarks:

For the codes $\mathrm{K} 1, \mathrm{~K} 2, \ldots . ., \mathrm{K} 6$, please refer to Table 1

${ }^{1)}$ Refer to Figure 1

${ }^{2)}$ Implying that the laminates consisted of single (one) species of wood waste origin

${ }^{3)}$ Implying that the laminates consisted of two different species of wood waste origin

${ }^{2)}$ and ${ }^{3)}$ species in the left-hand side order refers to the upper position of the laminate in the laminated wood, species in the middle order to the core position in the laminate, and species in the right-hand side order to the lower position.

The laminated assembly was further subjected to the manual hydraulic pressure at room temperature for 8 hours, and then conditioned also at room temperature for 7 days before the testing. The assembling of laminated wood for each of the manipulated compositions (Table 2) was replicated 3 times.

The procedures for testing of moisture content and density of the resulting 3-ply laminated wood followed the ASTM D 143-95 standard (Anonim, 1994). Meanwhile, the testing procedures of static bending, i.e. modulus of elasticity (MOE) and modulus of rupture (MOR) were in accordance with the JAS standard. (Anonim, 1996). The overall tested data were analyzed with completely randomized design with a single factor, i.e. manipulated composition of the wood laminates designated in particular codes (Table 2). When the effect of that factor was significant, the analysis proceeded with the Duncan's multiple range test (Steel and Torrie, 1995).

\section{RESULTS AND DISCUSSIONS}

\section{A. Moisture Content and Density}

Data regarding moisture content and density of 3-ply laminated wood were presented in Table 3. The moisture content varied about $4.00-13.90 \%$, and analysis of variance revealed that such variation was significantly affected by different manipulated compositions of the wood laminates. Judging from the fact that only single kind of glue (TRF adhesive) is used, the variation in moisture content could be due to different species of wood waste incorporated into the laminated assembly as laminates. Nevertheless, the overall moisture content could still meet the Indonesia's National Standard (Anonim, 2000), i.e. less than 14\%. 
Table 3. Density and moisture content of laminated wood

\begin{tabular}{|c|c|c|}
\hline $\begin{array}{c}\text { Codes referring to the manipulated } \\
\text { composition of wood laminates }\end{array}$ & $\begin{array}{c}\text { Moisture } \\
\text { content }(\%)^{2)}\end{array}$ & $\begin{array}{c}\text { Density } \\
\left(\mathrm{g} / \mathrm{cm}^{3}\right)^{2)}\end{array}$ \\
\hline $\mathrm{K}_{1}$ & 13.90 & 0.30 \\
\hline $\mathrm{K}_{2}$ & 9.00 & 0.68 \\
\hline $\mathrm{K}_{3}$ & 4.00 & 0.39 \\
\hline $\mathrm{K}_{4}$ & 6.40 & 0.52 \\
\hline $\mathrm{K}_{5}$ & 7.70 & 0.61 \\
\hline $\mathrm{K}_{6}$ & 5.20 & 0.40 \\
\hline
\end{tabular}

Remarks:

${ }^{1)}$ Refer to Table 2.

${ }^{2)}$ Average of three replications

The density of 3-ply laminated wood ranged from $0.30-0.68$ gram per $\mathrm{cm}^{3}$ (Table 3), and the analysis of variance confirmed that it was also affected by the different manipulated composition of wood laminates. Therefore, wood laminates with different species of wood waste origin was judged responsible for density variation. Consequently, it can happen that the density of laminated wood with the laminates composed of single wood species could be higher or lower than the one composed of different wood species (more than one species).

Results of further analysis using Duncan's multiple range test (DMRT) on density were described in Table 4. It showed that the density of laminated wood with the laminate composition pisang-bengkal-pisang (K6) was not significantly different from pisang-pisang-pisang (K3). It implied that the incorporation of bengkal species with pisang species in the laminated wood did not significantly affect its density in comparison with that composed of only pisang species. On the other hand, the densities of laminated wood with particular laminate compositions, designated as $\mathrm{K} 2, \mathrm{~K} 5, \mathrm{~K} 4$, and $\mathrm{K} 1$ were significantly different from each other.

Table 4. Duncan's multiple range test (DMRT) on the density of laminated wood elaborated through different manipulated composition of wood laminates (K1, K2, K3, K4, K5, and K6)

\begin{tabular}{|c|c|c|c|c|c|c|}
\hline \multicolumn{6}{|c|}{ Comparison between averages of density $\left(\mathrm{g} / \mathrm{cm}^{3}\right)^{1)}$} & $\begin{array}{c}\text { W }(0,05) \\
\left.\text { Df }=12^{*}\right)\end{array}$ \\
\hline $\mathrm{K} 2(0.68)$ & K5 (0.61) & $\mathrm{K} 4(0.52)$ & K6 (0.40) & K3 (0.39) & $\mathrm{K} 1(0.30)$ & 3.40 \\
\hline
\end{tabular}

Remarks:

${ }^{1)}$ Average of three replications

Figures with underline below are not significantly different

For the codes $\mathrm{K} 1, \mathrm{~K} 2, \ldots, \mathrm{K} 6$, please refer to Table 2

${ }^{\text {*) Critical value }}$ 


\section{B. Formaldehyde Emission}

One of the objections with the use of formaldehyde-containing adhesives is formaldehyde emission made from the glued products, since the emission in particular amount, can risk human health (Roffael, 1993). Formaldehyde emission entails the release of free formaldehyde contained in the glue. Free formaldehyde reveals the excess of formaldehyde which is not chemically reacting with tannin and resorcinol during the copolymerization reaction toward the formation of formaldehyde-incorporating adhesive/glue. Emission of formaldehyde from the experimented 3-ply laminated wood was described in histogram (Figure 2).

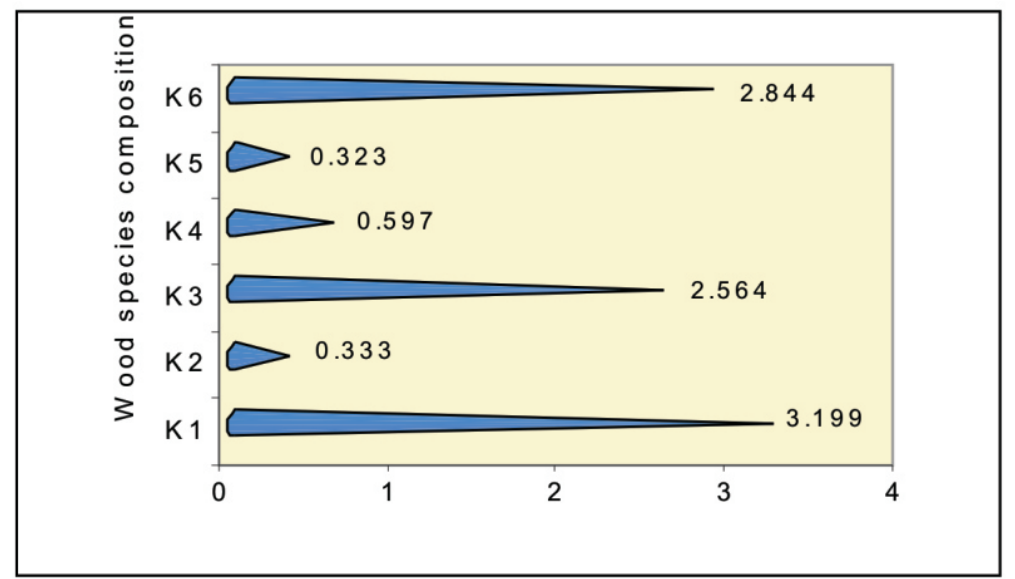

Figure 2. Histogram describing formaldehyde emission from 3-ply laminated wood Remarks: For the codes K1, K2, ..... K6, please refer to Table 2.

In average, the formaldehyde emission ranged about 0.323 - $3.199 \mathrm{mg}$ per liter (Figure 2). When abiding by the JAS Standard (Anonim, 2003b), the emission from the laminated wood whereby its laminates consisted of only single species, i.e. jambu-pisang-jambu (K5), the emission was as category $\mathrm{F}^{* * * *}$ (average $0.3 \mathrm{mg} / \mathrm{L}$, max. $0.4 \mathrm{mg} / \mathrm{L}$ ). Ultimately, when the laminates were the manipulated composition of jambu-bengkal-jambu (K4), the emission belonged to the category F*** (average $0.5 \mathrm{mg} / \mathrm{L}$, max. $0.7 \mathrm{mg} / \mathrm{L}$ ).

Judging from the JAS Standard, the formaldehyde emission from the experimented 3-ply laminated was still regarded low. This occurred because the used of TRF adhesive could afford water-resistant characteristics, thereby preventing the hydrolysis on the bonding between the inside adhesive components. In addition, the density of wood laminates presumably affected the emission. Santoso and Sutigno (1999) further asserted that the formaldehyde emission could be affected by wood density and extractive contents. As shown in Figure 2, laminated wood with low density tended to inflict much higher formaldehyde emission than the one with high density. The results appeared to be contradictory to those of Memed (1987), who examined formaldehyde emission from particleboard composed of particular single wood species, e.g. meranti merah and meranti kuning with their average specific gravity at 0.51. In this case, it turned out that 
formaldehyde emission from particle board of meranti merah wood (i.e. lower specific gravity) species was lower than that of meranti kuning wood (higher specific gravity).

The contradicting results caused of two reasons. Firstly, the used glue by Memed (1987) was Urea-Formaldehyde (UF) which has free formaldehyde higher $(2$ - $3 \%$ ) than TRF, namely $0.3 \%$ (Table 1). Secondly, the TRF glue is a weather boiling proof (MBP) type, therefore, it is water resistance glue and has no emission. Meanwhile, the UF is included an interior type glue which is not water resistance. The glue was hidrolized when affecting water and reached the emission.

\section{Bonding Strength and Failure in Laminated Wood}

In average, the bonding strength of 3-ply laminated wood as exemplified by its shear strength on the glueline (Table 5) ranged about $47.14-107.52 \mathrm{~kg}$ per $\mathrm{cm}^{2}$ (dry test) and $40.76-79.57 \mathrm{~kg}$ per $\mathrm{cm}^{2}$ (wet test). Laminated wood with the laminates consisting of more than one species (mixed wood species) tended to have bonding strength intermediary between those of its corresponding single wood species. The bonding strength of the experimented 3-ply laminated wood was higher than that of similar experiment using laminates of gmelina, tusam, and damar wood species procured as wood waste from plantation-forest logging and also using the same-glue type (TRF adhesive), i.e. $10.88-110.88 \mathrm{~kg}$ per cm${ }^{2}$ (dry test) and $4.54-43.73 \mathrm{~kg} \mathrm{per} \mathrm{cm}^{2}$ (wet test) (Santoso and Malik, 2004). This could be attributed to the differences in the specific gravity and extractive content of the wood laminate species.

Table 5. Bonding strength and wood failure of the assembled 3-ply laminated-wood

\begin{tabular}{|c|c|c|c|c|}
\hline \multirow{2}{*}{$\begin{array}{c}\text { Manipulated } \\
\begin{array}{c}\text { composition of the } \\
\text { laminates }\end{array}\end{array}$} & $\begin{array}{c}\text { Donding } \\
\text { strength } \\
\left(\mathrm{kg} / \mathrm{cm}^{2}\right)\end{array}$ & $\begin{array}{c}\text { Wood defect } \\
(\%)\end{array}$ & $\begin{array}{c}\text { Bonding } \\
\text { strength } \\
\left(\mathrm{kg} / \mathrm{cm}^{2}\right)\end{array}$ & $\begin{array}{c}\text { Wood defect } \\
(\%)\end{array}$ \\
\hline K1 & 47.14 & 100 & 40.76 & 80 \\
\hline K2 & 99.73 & 86.66 & 86.66 & 20 \\
\hline K3 & 103.89 & 100 & 71.46 & 80 \\
\hline K4 & 92.26 & 100 & 53.22 & 70 \\
\hline K5 & 86.93 & 100 & 69.22 & 56.66 \\
\hline K6 & 107.52 & 100 & 79.57 & 50 \\
\hline
\end{tabular}

Remarks: ${ }^{1)}$ Refer to Table 2. 
When referring to the standard as suggested by Tahir et al. (1988), most of shear strengths of the tested laminated beam could meet the standard, i.e. greater than $55 \mathrm{~kg}$ per $\mathrm{cm}^{2}$. Likewise, when it is compared to the JAS Standard (Anonim, 1996), the shear strength could comply with it, since the standard imposes the shear strength at $54-96 \mathrm{~kg}$ per $\mathrm{cm}^{2}$. Further, when it is compared with the experiment results of Karnasudirdja (1989) who acquired the shear strength of laminated wood assembled of kapur (Dryobalanops spp.) wood laminates (38 - $108 \mathrm{~kg}$ per $\left.\mathrm{cm}^{2}\right)$, meranti merah (Shorea spp.) wood laminates (47 - $77 \mathrm{~kg}$ per $\mathrm{cm}^{2}$ ), and teak (Tectona grandis L.f.) wood laminate (36 $84 \mathrm{~kg}$ per $\mathrm{cm}^{2}$ ) and used phenol-resorcinol-formaldehyde (PRF) adhesive with compression duration for 24 hours, the shear strength of the experimented laminated wood beam was also still higher. Similar case occurred to the results of experiment with laminated beam assembly (Sadiyo, 1989) whereby the laminates was a mixture of meranti merah, teak, merawan, kamper, and matoa wood species, bonded together with phenol-, resorcinol-, as well as phenol-resorcinolformaldehyde adhesive, under the trade name consecutively Aerodux 500, Cony bond KR-15 Y, and PA 302, and employing compression duration for 24 hours. The acquired shear strength was quite high indicating that the use of mixture laminates with different wood species origin appeared to be suitable for the assembling of construction-use laminated wood.

The effect of different manipulated composition of wood laminates on bonding strength of 3-ply laminated wood was analyzed with the DMRT test. It showed that results of the dry test as well as wet test on bonding strength were almost consistent from one code to other codes that designated the manipulated composition of wood laminates (Table 6).

Table 6. DMRT test elaborating effect of different composition of wood laminaes (K1, K2, K3, $\mathrm{K} 4, \mathrm{~K} 5$, and $\mathrm{K} 6$ ) on bonding strength of 3-ply laminated wood

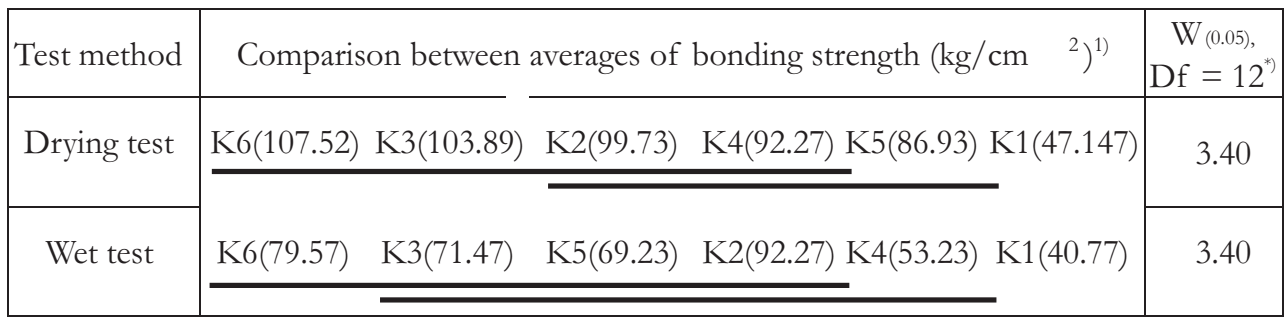

Remarks:

${ }^{1)}$ Average of three replications

Figures with underline below are not significantly different

For the codes $\mathrm{K} 1, \mathrm{~K} 2, \ldots, \mathrm{K} 6$, please refer to Table 2

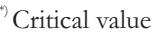




\section{Modulus of Rupture and Modulus of Elasticity}

In average, the modulus of rupture (MOR) of the 3-ply laminated wood varied from 455.62 $843.36 \mathrm{~kg}$ per $\mathrm{cm}^{2}$, and modulus of elasticity (MOE) from 35,985.49-104,323.63 $\mathrm{kg}$ per cm${ }^{2}$. Such considerable variation was presumably due to substantial differences in the density of wood laminae species and their extractive contents (Table 7). Further, the effect of different manipulated composition of wood laminates (Table 2) on the MOR and MOE was analyzed with the DMRT test (Table 8).

Table 7. Modulus of rupture (MOR) and modulus of elasticity (MOE) of 3-ply laminated wood

\begin{tabular}{|c|c|c|}
\hline \multirow{2}{*}{$\begin{array}{c}\text { Manipulated composition of wood } \\
\text { lamiane }\end{array}$} & \multicolumn{2}{|c|}{$\begin{array}{c}\text { Static bending strength } \\
\left(\mathrm{kg} / \mathrm{cm}^{2}\right)\end{array}$} \\
\cline { 2 - 3 } & MOR & MOE \\
\hline $\mathrm{K} 1$ & 455.62 & $61,243.17$ \\
\hline $\mathrm{K} 2$ & 843.36 & $35,985.49$ \\
\hline $\mathrm{K} 3$ & 529.40 & $74,792.91$ \\
\hline $\mathrm{K} 4$ & 700.22 & $104,332.63$ \\
\hline $\mathrm{K} 5$ & 797.14 & $58,545.91$ \\
\hline $\mathrm{K} 6$ & 520.07 & $44,710.42$ \\
\hline
\end{tabular}

Remarks: 1) For the codes, please refer to Table 2.

Table 8. DMRT test elaborating effect of different composition of wood laminates (K1, K2, K3, $\mathrm{K} 4, \mathrm{~K} 5$, and $\mathrm{K} 6$ ) on MOR and MOE of 3-ply laminated wood

\begin{tabular}{|c|c|c|c|c|c|c|c|}
\hline $\begin{array}{c}\text { Static } \\
\text { bending }\end{array}$ & \multicolumn{6}{|c|}{ Comparison between averages of static bending strength $(\mathrm{kg} / \mathrm{cm})^{2}$} & $\begin{array}{c}\text { W }(0.05) \\
\text { Df }=12^{*}\end{array}$ \\
\hline MOR & \multirow{2}{*}{$\begin{array}{c}\mathrm{K} 2(843.36) \\
\mathrm{K} 4(104,332.63)\end{array}$} & K5(797.14) & K4(700.22) & K3(529.40) & K6(520.07) & K1(455.62) & 3.40 \\
\hline MOE & & \multicolumn{2}{|c|}{$\mathrm{K} 3(74,792.91) \mathrm{K} 1(61,243.17)$} & $\mathrm{K} 5(58,545.91)$ & \multicolumn{2}{|c|}{ K6(44,710.42)K2(35,985.49) } & 3.40 \\
\hline
\end{tabular}

Remarks:

${ }^{1)}$ Average of three replications

Figures with underline below are not significantly different

For the codes $\mathrm{K} 1, \mathrm{~K} 2, \ldots, \mathrm{K} 6$, please refer to Table 2

${ }^{*}$ Critical value 
When referring to the strength classification of Indonesian wood (Den Berger, 1921 in: Hadjib, 2004), the experimented 3-ply laminated wood (Tables 7 and 8) that afforded the highest MOR and MOE could be categorized into strength class II - III.

The strength (MOR and MOE) of laminated wood assembled with high-density wood laminates tends to be greater than that with low-density wood laminae. Further, when using the combination of high- and low-density wood laminates, the strength of the resulting laminated wood can be intermediate between higher-strength and lower-strength laminated woods. In this experiment results, it revealed that the laminates prepared from 3 species of wood waste from forest logging, bonded together with TRF adhesive afforded satisfactory gluing characteristics and hence were suitable for the assembling of reconstituted wood products (e.g. laminated wood) for exterior and structural uses. Suitability for exterior uses was indicated high bonding strength (shear strength) of the resulting laminated wood either in wet or dry tests.

The MOE of the 3-ply laminated wood assembled of wood laminates according to their manipulated composition, i.e. K1, K2, K3, .., K6 (Table 2) entirely revealed significant difference from one to others (Table 8). Similar situation also almost occurred to the MOR, except the one with the manipulated composition designated as codes K3 and K6. These phenomena were in fact consistent with those occurring to density, formaldehyde emission, and bonding strength of the experimented 3-ply laminated wood as previously described.

\section{CONCLUSIONS AND RECOMMENDATIONS}

1. To enhance added value and utilization efficiency of forest resources (i.e. wood wastes), their assembling (processing) into laminated wood can be one of the several beneficial attempts.

2. Wood wastes of three species (i.e. jambu-jambu, pisang-pisang and bengkal) obtained from forest logging, after being converted into thin wood pieces (laminates) revealed satisfactory bonding characteristics when bonded using thermo-setting tannin-resorcinol-formaldehyde (TRF) adhesive, and hence were suitable for the production of exterior type laminated wood for structural uses.

3. The resulting 3-ply laminated wood assembled with the manipulated laminate composition could be categorized into strength class II - III, rendering it suitable for various uses under severe outdoor conditions.

4. The resulting 3-ply laminated wood with low density inflicted higher formaldehyde emission than the one with high density.

\section{LITERATURES CITED}

Anonim, 1994. Standard methods of testing small clear specimen of timber. Annula Book of ASTM Standard Vol. 4 Sec. 4. Construction. Philadelphia. 
1996. Japanese Agricultural Standard for Structural Glued Laminated Timber. Japanes Agricultural Standard (JAS), Japan Plywood Inspection Corporation (JPIC). Tokyo.

2000. Venir lamina. Rancangan Standar Nasional Indonesia: SNI-5008.9-2000. Badan Standardisasi Nasional. Jakarta.

2003a. Eksekutif Data Strategis Kehutanan 2003. Departemen Kehutanan. Jakarta.

2003b. Japanese Agricultural Standard for Plywood. Japanes Agricultural Standard (JAS), Japan Plywood Inspection Corporation (JPIC). Tokyo.

Budiaman, A., 2000. Kuantifikasi kayu bulat kecil limbah pemanenan pada pengusahaan hutan alam. Jurnal Teknologi Hasil Hutan Vol XIII(2): 34-43.

Dansoh, A.B., A. Koizumi and T. Hirai, 2004. Bending strength and stiffness of glued butt-jointed glulam. Forest Product Journal 54(9): 40-44.

Feirer, J.L., G.R. Hatchings and M.D. Feirer, 1997. Carpentry and Building Construction, 5th ed. Glence/McGraw Hill, New York, pp. 91-99.

Hadjib, N. 2004. Sifat fisik dan mekanik kayu dan bambu. Diklat Pelatihan Kompetensi Tenaga Laboratorium Pengolahan Kayu dan Bambu. Pusat Penelitian dan Pengem-bangan Teknologi Hasil Hutan, Bogor.

Kardasudirdja, S. 1989. Prospek kayu Indonesia sebagai bahan baku industri kayu lamina. Makalah pada Seminar Glue Laminated Lumber (Glulam), 15 Juni 1989, Jakarta.

Memed, 1987. Emisi gas formaldehida papan partikel dari beberapa jenis kayu. Jurnal Penelitian Hasil Hutan Vol. 4 No. 2, Bogor.

Moody, R.C., R. Hernandez, and J.Y. Liu. 1999. Glued structural members, In Wood HandbookWood as an Engineering Material. Gen Tech. Rep. FPL-GTR-113, USDA. Madison.

Roffael, E., 1993. Advanced Wood Adhesive Technology. Marcer Dekker, Inc. New York.

Sadiyo, S. 1989. Pengaruh kombinasi jenis kayu dan jenis perekat terhadap sifat fisis dan mekanis panel diagonal lambung kapal. Fakultas Pascasarjana, IPB Bogor. Unpublished Thesis.

Santoso, A. dan P. Sutigno, 1999. Pengaruh jenis kayu dan jumlah lapisan terhadap keteguhan rekat dan emisi formaldehida kayu lapis. Prosiding Seminar Nasional MAPEKI Buku II, Yogyakarta.

Santoso, A. dan G. Pari, 2001. Pemanfaatan tanin dari kulit pohon mangium sebagai bahan perekat kayu lapis. Proceeding of seminar environment conservation through efficiency utilization of forest biomass. Kerjasama Debut Press-Jurusan Teknologi Hasil Hutan UGM-JIFPRO. Yogyakarta.

Santoso, A. dan J. Malik, 2004. Pengaruh jenis perekat dan kombinasi jenis kayu terhadap keteguhan rekat kayu lamina. Bahan publikasi Jurnal Penelitian Hasil Hutan, Pusat Penelitian 
dan Pengembangan Hasil Hutan, Bogor.

Sinaga, M., 1989. Pengaruh jumlah lapisan terhadap sifat mekanis kayu lamina jenis hutan tanaman industri. Prosiding Diskusi Sifat dan Kegunaan Jenis Kayu HTI. Badan Litbang Departemen Kehutanan. Jakarta.

Steel, R.G.D dan J.H. Torrie. 1995. Prinsip dan Prosedur Statistika: Suatu pendekatan biometrik. Edisi kedua. PT. Gramedia Pustaka Utama. Jakarta.

Sugiri, E.W., 1981. Penelitian Persentase Limbah Pembalakan Tegakan Meranti berdasarkan Volume Total di Kesatuan Usaha PT Inhutani II Kalimantan Selatan. Thesis Fahutan, IPB. Bogor.

Tahir, P. Md., M.H. Sahri and Z. Ashari. 1998. Gluability of lesser used and fast growing tropical plantation hardwood species. Faculty of Forestry Universiti of Putra Malaysia. Selangor.

Widarmana, S., 1984. Studi kemungkinan pemanfaatan limbah kayu untuk panil komposit sebagai bahan bangunan. Kerjasama Kantor Menneg KLH dan Fakultas Kehutanan IPB. 